Higher Education 8 (1979) 683-699

(c) Elsevier Scientific Publishing Company, Amsterdam - Printed in the Netherlands

\title{
SADHUS NO LONGER: RECENT TRENDS IN INDIAN STUDENT ACTIVISM
}

\author{
N. JAYARAM \\ Department of Sociology, Bangalore University, Bangalore, India
}

\begin{abstract}
The main thesis of this paper is that student unrest in India is not always necessarily a manifestation of juvenile delinquency, and given certain conditions can change into an articulated movement. This is substantiated through an analysis of the nature and content of student activism in India during the seventies, covering an important phase in the history of modern India, namely, the state of "Internal" Emergency. Part One analyses the genesis and growth of the student movement in 1974-1975. Part Two discusses the suppression of student activism during the Emergency. The rise and fall of the Youth Congress during this period is outlined. Part Three presents a scenario of student unrest in the post-Emergency period and highlights the reappearance of the sixties'-type of the student agitations. The article summarizes the development of the student movement during the pre-Emergency period, accounts for the reversal in the movement since the end of Emergency, and discusses the prospects of the re-emergence of such a movement.
\end{abstract}

\section{The Pre-Emergency Scene}

The history of student activism in India has been a chequered one as part of the nationalist movement. It is often argued that the nature and content of student activism have undergone a qualitative change since Independence (Altbach, 1968a; p. 17, Ross, 1969, p. 19). The crux of the argument runs as follows: while the pre-Independence student movement had a single goal, namely, independence for India, and was linked to the country's life and politics, the wave of student agitations since 1947 has not been directly political but has concerned local and non-ideological issues. Also, student agitations have become basically disruptive and lost the character of a movement.

In the sixties, the colleges and universities were the scene of student agitations. It is estimated that in 1966 there were 2,206 student demonstrations, of which 480 were violent (Altbach, 1968a, p. 53). The prominent student agitations till 1968 have been recorded by Altbach (1968a), and the Vishwa Yuvak Kendra (1973, pp. 59 - 98) has documented 59 student agita- 
tions which have obstructed the normal functioning of academic institutions during 1968.

A close examination of the series of student strikes in Karnataka (Ross, 1969), Benares (Ray, 1977), Calcutta (Dasgupta, 1974), and elsewhere (Vishwa Yuvak Kendra, 1973) in the sixties, and in Delhi (Singhal, 1977) during the early seventies highlights that in the sixties the student agitations started gradually regaining an organized form. Student unions came to be increasingly influenced by political parties though devoid of ideological fervour. But it was only in 1974 that the student agitations started manifesting characteristics of an articulated movement. It originated in Gujarat, spread to Bihar and was later transformed into a country-wide movement.

\section{GUJARAT: NAVNIRMAN SAMITI}

The rising inflation of the early seventies marked the turning point in the economic scene and paved the way for socio-political changes. It is reported that between 1971-72 and 1973-74 the per capita availability of food grains fell by 11 per cent and industrial production stagnated, and whereas the wholesale price index rose by 33 per cent, the per capita income declined by 4.2 per cent. During 1972-73, prices of food grains, edible oil, vegetables and meat rose by 30 to more than 100 per cent. Such essential commodities as rice, wheat, cooking oil and kerosene became scarce (Hiro 1978: 255-257).

Spiralling prices and growing scarcity meant untold hardship to the people, who, especially in the urban. areas, blamed the ruling Congress government for this and began expressing their discontent through rallies and strikes. The opposition political parties joined the protest. Instead of stopping the sliding of the living standards of the masses, the Congress government became defensive and resorted to the use of force to quell the protest. During the first half of 1973, the army was called out seventeen times to restore law and order - a record in post-Independence India (Race Today, Aug. 1975, p. 179). This only aggravated people's antagonism towards the government. This also marked the beginning of the systematic student movement directed against the Congress government, whose first phase occurred in Gujarat.

In December 1973, the resident students at an engineering college in Ahmadabad were asked to pay a 41 per cent higher mess bill the following month. The striking students turned violent and burnt public property. The Congress government in Gujarat resorted to ruthless handling of the situation. A large contingent of police was sent to quell the unrest. But this was counter-productive, as the police excesses further widened the existing alienation between the students and the people on the one hand and the government on the other. The movement spread like wildfire throughout the 
state under the banner of Navnirman Samiti. In the course of four weeks of riots in January-February 1974, engineered mainly by the students, the police had to open fire on people 347 times, three times the annual average for the country as a whole (Race Today, August 1975, p. 179).

All this led to the imposition of President's Rule in Gujarat on February 2, 1974, but the assembly was kept in suspended animation, with the hope of re-forming the Congress government once the tension cooled down. The strategy of the central government betrayed its ulterior motives and another bout of agitation occurred demanding the dissolution of the state assembly and the holding of fresh elections. The students evolved the novel technique of pressuring the legislative assembly members to resign their seats. Seventeen Congress members responded to the students' pressure and resigned their seats. On March 17, 1974 the state assembly was dissolved. This was a great achievement for the student movement.

A latent consequence of this movement was the acquisition of a moral halo by the future Prime Minister, Morarji Desai, who had joined the struggle started by the students, and started on a fast unto death supporting the demand for the dissolution of the state assembly. He conveniently described the outcome of the students' struggle as a "victory of the people's struggle". While exhorting the students to carry on their planned reconstruction work with courage and conviction, he pleaded for non-violence.

"Here was youth power channelized to achieve something concrete - a phenomenon unthinkable till then" (Pandit, 1977, p. 142). The government little realized that it was facing the beginnings of a mass student movement. It was at this juncture that Jayaprakash Narayan realized the significance of student power. The Gujarat incident provided the inspiration that Narayan had been waiting for.

\section{BIHAR: CHHATRA SANGHARSHA SAMITI}

Jayaprakash Narayan, an erstwhile Sarvodaya leader, was planning to lead a people's movement against what he described as widespread corruption in the country. Encouraged by the achievements of the student movement Navnirman Samiti in Gujarat, Narayan gradually moulded students of Bihar.

On March 18, 1974, the Governor of Bihar was due to address the Bihar legislature. Narayan and the students tried to prevent the governor and the legislators from reaching the legislature. The state government reacted with an excessive show of police force and the next two days witnessed unprecedented violence. The then Union Home Minister admitted that during those two days the police had opened fire nine times resulting in the death of eight and injury to seventy-two people.

In April 1974 a unique protest march called the Maun Julus took place. 
Volunteers of various non-violent groups were selected under oath to practice peace, silence, and thoughts of goodwill against the enemy. Led by Narayan they silently marched through the streets of Patna. It turned out to be an echo of the national conscience, and was described as "a deadening calm pregnant with typhoon".

In June 1974, Narayan called on the students to stay away from the classroom for one year so that they could fully devote themselves to the movement. This call was reiterated by the Chhatra Sangharsha Samiti which demanded the immediate closure of all the universities and colleges in Bihar. The state government was determined to hold the annual examinations, which had already been postponed once. The political atmosphere in the state was turning turbulent as the intermediate examination approached.

It is also important to note the alliances that were forged during this period. In Gujarat, the student wing of the right Jan Sangh combined with that of the Socialist Party to form the Navnirman Samiti, and the Congress (0) supported the Samiti. The same combination clicked in Bihar under the banner of Chhatra Sangharsha Samiti. The ultimate fruit of such a combination was the development of a united opposition political front, which became the Janata Party which later took power at the Centre and in a few north-Indian states. It is "a kind of political illogicality that went way beyond the rational understanding of those who had learnt to play politics only in the Western ways" (Pandit, 1977, p. 147).

By June 1975 the atmosphere was characterized by disenchantment and disillusionment. The central government grew increasingly repressive. The movement was spreading to other parts of the country. The popular reaction to the Congress rule was indicated by the fact that the party lost the Gujarat mid-term election in June 1975. On June 12, 1975 the fateful Allahabad High Court judgement was handed down declaring the election of Indira Gandhi, the then Prime Minister, to the Lok Sabha null and void. The opposition was preparing to launch a national campaign to secure her resignation. But on June 26 the presidential proclamation declared a state of "Internal" Emergency.

\section{The "Internal" Emergency and Suppression of Student Activism}

Whatever may be the explanation about the events leading to the Emergency, the period will go down in the history of India as a brutal and ignominious one. We shall confine ourselves to the plight of student activism during this period. Recognizing the disruptive potential of the student movement, Mrs. Gandhi's government dealt harshly with student activism and jailed many key student leaders. 
The various measures taken by the Congress government to suppress student activism may be broadly categorized into direct and indirect. Among the direct measures, at the outset, the government arrested, detained, and tortured the student leaders belonging to or sympathetic to the opposition parties. In some universities, such as Delhi University, intelligence agents were enrolled as students to discover the secret structure of student activism and underground resistance. Students who were found to be in any way sympathetic to the opposition party or showing opposition to the ruling party or its programmes were blacklisted and thrown out of the college or university or denied admission.

Secondly, the students' unions were depoliticized. Elections for students' unions were banned, and directives were issued for the formation of student "associations" through nominations or indirect election. The functions of such "associations" were to be purely cultural. Finally the government propagated the idea of the "constructive role of students in the implementation of the ' 20 point' programme and national development".

While the foregoing dealt a death blow to the nascent student movement, other measures were instituted under the subterfuge of educational reforms. The universities were advised to semesterize courses starting with the first-degree level. Not only was the so called "semester system" a sham of the system working in the Western countries - as it involved a change neither in the content nor in the method of teaching, but only the multiplication of examinations and greater control over the students - but it was also introduced almost overnight with absolutely no preparation. Under the semester system, the students were constantly kept busy with course work and examinations, giving them little time to think about anything else.

Secondly, the government tried to appease the students belonging to the so called "Backward Classes" by proclaiming measures - like reservation of seats, concession in fees, etc. - in addition to the existing constitutional reservations and facilities for the benefit of students belonging to the Scheduled Castes and Tribes. This resulted in a discernible cleavage among the students whose interests now stood divided, and this had pernicious consequences for the student movement.

Finally, in some states, such as Maharashtra and Karnataka, the governments promulgated ordinances reorganizing the structure and functioning of universities, resulting in the curtailment of academic freedom within and autonomy of the universities on the one hand, and the increased governmental interference in, and the undemocratic functioning of the universities on the other hand.

\section{NEHRU UNIVERSITY UNDER THE EMERGENCY}

Jawaharlal Nehru University (JNU) in New Delhi is one of India's most 
prestigious universities. Focusing on post-graduate study and with a small and highly articulate student population, the university has been one of the most radical in India. It was not surprising that government repression was especially intense at JNU, starting with the arrest of sixty student leaders in July 1975, and continuing for the entire period of the Emergency. These arrests marked the birth of a resistance among the students, led mainly by the Students Federation of India (SFI), which engaged in underground activities. It kept a steady stream of handouts, bulletins, and other materials going in order to inform students of government actions and to keep the spirit of dissent alive.

With the onset of the Emergency, university authorities acted to restrict the Students' Union, which was somewhat unique in India in that it was completely independent of the university administration. Membership, which had been mandatory, was shifted to voluntary, thus weakening the organization. The university also imposed "norms of behaviour for students" without student input, and this was also condemned by the students. Finally, university authorities expelled a number of students who were sympathetic to opposition groups. The Students' Union called for a boycott of classes on August 22, 1975 and the faculty supported this boycott. While the boycott was almost completely successful, the university kept up its pressure and continued to deal harshly with dissidents. Another student strike was called in September, and this was also successful. University authorities called in the police and more student activists were arrested.

While most students supported the resistance and heeded the boycotts and strikes, the student community was not completely united. The All India Students' Federation (AISF), student group of the pro-Moscow Communist Party of India, which at the time supported the Emergency, denounced the resistance and advocated a return to normalcy on the campus. The continuing factional disputes between the leftist SFI and the AISF no doubt played a role in this situation, which resulted in a loss of support for the AISF.

New university policies reduced the Students' Union to a cultural association, eliminated the democratic structure of the organization, provided academic authorities with power to nominate individuals for union positions, and in general changed the nature of the organization. The right of the union to protest university decisions was eliminated, and the union was provided with a staff advisor who had veto power over all decisions. The university took authority to dismiss any student from the union or from the university. After implementing these new regulations, the Registrar of the Univeristy informed the Students' Union leadership that they had been ousted and the existing union "derecognized".

The dissolution of the Students' Union heralded the iniquitous success of the university authorities. On November 7, the "ex-president" of the Students' Union was expelled from the university for six months and on Novem- 
ber 11 he was arrested and detained under the Maintenance of Internal Security Act.

In this situation, the AISF abruptly changed its stand. In its pamphlet entitled "The Truth About 'Resistance"" it vehemently criticized the SFIled resistance, and accused the SFI of working against its candidate in the Delhi University Students' Union elections. It appealed to the honest section of the SFI-influenced students to "down with left opportunism" and "professional hoodwinkers", and return to the broad democratic left movement.

Thus came to an end the saga of resistance which nevertheless continued once the Emergency was lifted. It is the commitment of the SFI to the resistance and the vacillation of the AISF during the Emergency that accounts for the immense popularity of the former and the weakness of the latter on the JNU campus today.

\section{SUPPRESSION IN DELHI UNIVERSITY AND ELSEWHERE}

While the saga of suppression and resistance in JNU was unique for its sophistication, the suppression of student activists in Delhi University and elsewhere was also significant. The case of Hemant Kumar Vishnoi is noteworthy. Vishnoi was closely associated with the rightist Rashtriya Swayam Sevak Sangh and the Akhil Bharatiya Vidyarthi Parishad (hereafter Vidyarthi Parishad), which had captured about seventy percent of the students' unions in the university, and was the target of government surveillance. His election as Secretary of the Delhi University Students' Union immediately caught the attention of the government, since Vishnoi and his Vidyarthi Parishad associates had won the university elections on issues involving the Gujarat-Bihar movement.

On the eve of the Emergency, Vishnoi was away in Rhotak attending a students' camp. On his return to Delhi he had to go underground as he learnt that the President of the Delhi University Students' Union had been arrested and that the police were looking for him. Since most of the leaders had gone underground, it was difficult if not impossible for him to establish contact with his fellow Parishad leaders. A meeting with the General Secretary of the Vidyarthi Parishad resulted in rough plans of action. The police, however, sensed the situation; the underground office was raided and the General Secretary of the Vidyarthi Parishad was arrested.

On the eve of the reopening of colleges the police rounded up about fifty leaders who were considered to be influential. The Sangharsha Samiti issued a pamphlet condemning the arrests and urging the students to fight such repression and called upon them to observe July 25 as a "close-the-university demand day". With more policemen than students on the campus, July 25 and 26 proved to be days of terror. In all 186 people were arrested, including some 120 college teachers. 
In the light of the increasing difficulty and risk involved in communication a new method was evolved. Picnics were organized in open places and parks where underground people could meet and exchange information. At one such "picnic", following information leakage, Vishnoi was arrested along with other students. Then followed the inhuman third-degree methods of torture of Vishnoi and his associates to get secrets about the underground movement.

This, however, was not an isolated incident; the suppression of student leaders was almost a national phenomenon.

Held under the Defence of India Rules, or Maintenance of Internal Security Act, they [student leaders] came from universities and colleges - an incomplete list alone contains over one hundred institutions ... from one end of India to another (Selbourne, 1977, p. 166).

Thus, the largest and most valuable contribution to the struggle of 1975-1977 came from the students and youth. While the government apparently controlled and contained the student unrest through repressive tactics and by creating a fear psychosis in the community of students, the continuation of such a trend only aggravated the latent anxiety and anger of students. The pressure burst once Lok Sabha elections were announced and student leaders released. A new wave of student awareness was evident in early 1977. The students took the election as a challenge and became involved in campaigning for their respective parties. The students played a crucial role in the defeat of the ruling Congress government and the election of the first alternative government in the political history of India since Independence.

\section{THE RISE AND FALL OF THE YOUTH CONGRESS}

In any large and plural society it will be difficult to find a political party without a youth wing. The youth wings act as recruiting groups for the newly franchised young men looking for a political party. They bridge the generation gap and give a cosmopolitan character to the parent bodies. Further, they may be the only source of uncontaminated - though often naïve and inflexible - idealism for the party, serving as a corrective to the cynicism and the will to compromise of the veteran members (Mehta, 1978, p. 73).

In a study of student politics in Delhi University, Oommen observed that since political parties believe in the slogan "catch them young", they are eager to establish contacts with students and eventually "use" them for political purposes. The student leaders' perception that they cannot become "real" leaders unless they establish contacts with political parties facilitates 
the process of politicization (Oommen, 1974, p. 791). It is in this light that we should understand the emergence of the Youth Congress during the Emergency.

In the pre-Emergency days the Youth Congress was the rather weak youth wing of the Indian National Congress. It had very few members, lacked ideology, and had no voice in the parent body. Thus, as a pressure group it had virtually no impact. This hitherto dormant band got activized during the Emergency, as it provided the springboard for the assumption of power by Sanjay Gandhi, the then Prime Minister's son. With his sycophants hailing him as "the beacon of hope of an awakened India" and "the rising sun on the political horizon", he in fact emerged as the second most powerful politician in the country during the Emergency.

Under his patronage the Youth Congress acquired undue recognition, and his mother - the Prime Minister - proclaimed at the Gauhati session of the All India Congress Committee that "the Youth Congress had taken the thunder out of the parent body's session". The Congressmen who had watched this with apprehension were the first to be arrested during the Emergency.

Although never elected to a formal Youth Congress post, Sanjay Gandhi was coopted to its Executive Council, and then exercised almost dictatorial power in the organization. He increased the membership from 700,000 to $6,000,000$ by enrolling anyone under 35 who was willing to pay one rupee. Many, on seeing that the Youth Congress had power within the Congress hierarchy, were eager to join it. As one observer put it:

The Youth Congress became 'an umbrella' organization which sheltered a variety of goondas, thugs, pickpockets, criminals - all the 'bad characters' and 'anti-social' elements police usually keep a record of (Mehta, 1978, p. 85).

Sanjay Gandhi cleverly committed the Youth Congress to a series of apolitical goals such as family planning, tree planting, abolition of caste and the dowry system, eradication of illiteracy and slum clearance. This was described as a "cultural revolution", but in fact the organization proved mainly to be a political weapon for Sanjay Gandhi in his various struggles within the government.

In due course it was recognized that the ultimate strategy of the Youth Congress under Sanjay Gandhi was to execute a coup in the ruling parent body. This was given concrete expression in 1977 at the time of the Lok Sabha election, when the Youth Congress put in a claim for 200 of the 540 seats. This raised doubts in the minds of veteran Congressmen and the sudden exit of the Methuselah of Indian politics, Jagjivan Ram, changed the situation overnight. The Congress party was reluctant to antagonize any more old stalwarts by inducting youth into the election. In the final analysis, the Youth Congress secured less than ten nominations and later lost them all. 


\section{Student Activism in the Post-Emergency Period}

Contrary to expectations, the end of the Emergency did not bring peace and tranquility to the campus. According to an official estimate, there were 7,520 incidents of student unrest in 1977, of which 1,146 were violent. The corresponding figures for 1978 till August stood at 5,838 and 1,050 respectively. State-wise, student unrest was more pronounced in Uttar Pradesh $(22 \%)$, Maharashtra $(21 \%)$ and Bihar (13\%). Moreover, the percentage of violent incidents was only 15 for the whole of 1977 whereas the corresponding percentage for the first eight months of 1978 was 18 . What is the nature of student unrest in this period?

\section{MARATHWADA RIOTS}

An exceptional feature of Marathwada University in Maharashtra is the polarization of students along caste and community lines. On one side is the Nagasena Vana campus encompassing four colleges and hostels run by the People's Education Society started by Dr. B. R. Ambedkar, champion of the untouchables. Adjacent to it is the university campus proper. Over ninety per cent of the students on the Nagasena Vana campus are Harijans. While the government colleges reserve thirty-four percent of the seats for students belonging to the Scheduled Castes and Tribes, their number in private colleges is negligible according to the Annual Report of the University for 19771978.

In July 1978, the newly formed Janata and Rebel Congress coalition ministry in Maharashtra decided to rename the Marathwada University after Ambedkar. Whatever may be the motive behind this political decision, there followed riots which originating on the campus in Aurangabad spread like wildfire throughout the State.

On the campus, the renaming issue originated through a combination of the need to mark the fiftieth anniversary of Ambedkar's Mahad Satyagraha with a fitting memorial and certain personal manoeuvres. The campaign had lasted for over 18 months and was almost incident free. But the aggressiveness of Dalit Panther (a Harijan group) incited Vidhyarthi Kruthi Samiti. The issue of protective discrimination enlarged the renaming of the university into a symbolic act and it became a focus of a confrontation between the Harijans and the caste Hindus.

A ten-day-old state-wide strike which had resulted in loss of life and property was finally called off on August 6, 1978 - even as violent incidents were reported for the first time from Bombay, Poona, Nanded, and Nagpur on the assurance of the chief minister that no decision would be taken unless and until an amicable settlement acceptable to all concerned was found. There now prevails an uneasy calm in Marathwada University. 
The Pantnagar Agricultural University was the only campus in Uttar Pradesh which the police had never entered to tackle law and order problems. But in April 1978, it saw a protracted and violent strike accompanied by an equally brutal and persistent police action. The incident originated as a farm workers' agitation and developed into a campus versus police affair.

The Pantnagar Karmachari Sangathan, which had been set up in October 1977 to represent the interests of nearly 8,000 migrant farm workers, submitted a memorandum to the vice-chancellor threatening to go on strike if their demands were not met. After two unsuccessful agreements, and the suspension of ninety workers, the Uttar Pradesh government declared any strike in the university illegal. The workers' retaliation resulted in the arrest of 100 workers and the posting of Provincial Armed Constabulary on the campus.

In March 1978, a procession of 6,000 demonstrators demanded among other things the repeal of the government decree declaring the strike illegal, the withdrawal of the constabulary from the campus, and the dismissal of the vice-chancellor. When the demands were not met, the strike was resumed and later turned violent. The constabulary opened fire on the strikers resulting in the death of fifty-one persons and injury to many more. The university was closed on the same day. In view of the prevailing tension, the university which was reopened on April 19, was closed again on May 5.

It appears that the rich farmers of the area were interested in scuttling the strike, as they apprehended that any hike in the wages of the university farm workers would have repercussion on their own workers whom they had been exploiting with strong-arm tactics. This was effectively countered by the parties of the left, and some left-wing student leaders paid regular visits to Pantnagar to confer with the leaders of the strike.

With 1,100 head of cattle and 19,000 fowl uncared for, and cane and wheat crops likely to be ruined, the indefinite closure of the university by striking farm workers posed a threat of great physical and monetary loss to the university. However, the situation eased with the resignation of the vicechancellor in June 1978.

The Pantnagar incident is unique in several respects. The Action Committee of the university did not allow the strike to be politicized, and in fact, it explicitly requested the politicians to keep away from it. Moreover, the post-strike behaviour of Pantnagar students was exemplary. After the strike, but for the fullest cooperation extended by the students, hundreds of head of cattle would have perished, milk supply ceased, and sanitary arrangements on the campus collapsed. Most important, the strike was initiated by the workers of the university and the students joined it, with the teachers following suit. Perhaps this is the first instance in which the intelligentsia came out 
of its closed circle to join the workers' struggle, thus heralding a new trend in campus activism in the country.

\section{STUDENT UNREST IN OTHER PARTS OF INDIA}

- College students in Bangalore went on strike demanding among other things the institution of a judicial inquiry into the university affairs, removal of the vice-chancelor and removal of the police station from the university campus. In October the Harijan boarders of the university's Jnanabharati Men's Hostel demonstrated protesting against the "harassment and discrimination" of hostel inmates by the chief warden. Students of a Christian women's college went on strike - for the first time in the history of the college demanding democratic election to the students' union of the college.

- In Hyderabad, students went on strike in September 1978 demanding the resignation of a woman Minister for Women's Welfare, who had "degraded Indian women publicly". The vice-chancellor of Osmania University announced the closure of all the forty-five colleges in Hyderabad and Secunderabad for several weeks in view of the disturbed conditions on the campus resulting from clashes between two groups of students belonging to the Progressive Democratic Students' Union and the Vidyarthi Parishad.

- In 1979, students throughout Tamil Nadu went on strike in sympathy with striking teachers. In Pondicherry, about 4,000 students organized a procession to protest against the proposal to merge Pondicherry with the neighbouring State of Tamil Nadu.

- In Bombay, the students of St. Xavier's College went on strike in 1977, against the continued attempts of the principal and the management to stifle free expression and democratic rights in the college. In August 1978, a strike against increased tuition charges culminated in the seizure of Bombay University by the students, whereby the university officials, including the vicechancellor, were locked out of their offices.

- In Patna, the vice-chancellor's security guard opened fire when the law examinees started hurling chairs at him on September 13, 1978. The incident was sparked off when the squad detected the use of unfair means by the examinees, who later walked out of the examination hall with their question papers and answer books. In Bihar and Uttar Pradesh students agitating against the policy of protective discrimination in favour of the "Backward Classes" almost paralysed academic life for over six months.

There has been a sharp rise in student unrest in India since the end of the Emergency. In 1977, agitators in several universities demanded action against the "Emergency excesses". The reasons for a large number of recent agitations are non-academic. Besides politically motivated agitations, issues like restoration of democratic rights, protective discrimination, renaming of universities, alteration of state boundaries, police excesses, and purely local 
issues, such as bus fare increases, have disrupted the normal functioning of educational institutions.

The repeated occurrence of student unrest poses a major headache to the government and educational authorities. Intrusions by the police into a university campus has become a frequent occurrence and is no longer news. The two-day Conference of State Governors held in March 1979 has expressed grave concern at the growth of student indiscipline in the country and has called for firm steps to curb it.

\section{Conclusion: Some Theoretical Considerations}

It is not at all surprising that a segment of a society's student population should be involved in activism that is militantly directed against the status quo.

It can be strongly argued, as C. Wright Mills argued, that students are the one group who will continue to supply recruits for such causes, even when no other stratum is available. A completely inactive student body is a much more curious phenomenon historically than one which is involved to some degree in activism (Lipset, 1972, p. 263).

The explanations about the causes, content, and nature of student unrest are never the same or uniform in all the cases, because the manifestation of student unrest in any society is not ahistorical or isolated from its socio-economic milieu. Analyses of student unrest in India have highlighted various causes, from "high jinks" or the desire for "fun" (Ross, 1969, p. 17) on the one hand to acute politicization of academia (Ray, 1977, pp. 3-5) on the other. A recent survey of student indiscipline by the All India Committee of World Brotherhood lists the following causes:

\footnotetext{
... too much leisure time, political participation, sex problems, poor student - teacher relation, lack of facilities for representation of complaint, anxiety over examination, student frustration (anxieties, separations from friends or family, hurt feelings, unsatisfied ambitions, financial difficulties), inadequately handled student misbehaviour, and emotional immaturity (quoted in Jafar, 1977, pp. xv-xvi).
}

According to Singhal (1977, pp. 34-43), in addition to the economic factors, organizational climate and political interest in the campus, belief in agitational tactics and faith in violence, perception of political and governmental interference, and absence of a code of conduct are significant causal variables. Ghosh (1971) has argued that student unrest in the country is being deliberately fostered by certain foreign agencies.

As regards the form that the unrest takes, expression of resentment (both verbal and written); boycott of classes and walkout from examination 
halls; demonstrations, rallies and courting arrests; strikes, dharnas and gheraos; and damage to public property, assault and intimidation are found to be salient (Singhal, 1977, pp. 128-129). As Shils (1968b, pp. 5-6) points out, the students invariably attack disconnected symbols like vice-chancellors, district collectors, police officers, post offices, railway stations, etc., rather than the center of the system, namely, the government or the regime.

Generally, student agitation fits into Shils' characterization as a manifestation of juvenile delinquency (Shils, 1968a, 1968b). The manifestations are severe and recurrent as some impunity is always assured. But in the absence of official patronage and support, they tend to be unstable and short-lived (Altbach 1968b, p. 198).

This article observes that student unrest is not always necessarily a manifestation of delinquency, and given certain conditions, it can develop into a concerted social movement. We have seen how the sixties witnessed a spate of student agitations, how in the early seventies the student agitations developed into a mass movement to be ruthlessly suppressed during the Emergency, and how, once the Emergency was lifted, the sixties' type of agitations have reappeared. What accounts for this rhythmical alternation between growth and decline of a student movement?

According to Smelser (1962), a society must be structurally conducive to the development of the type of elementary collective behaviour that will lead to a social movement before one can arise. In other words, the condition of the society must be such that new types of behaviour are possible, or are likely to appear. He identifies the presence of structural strains accompanied by feelings of anxiety and frustration as characterizing such a situation. This situation must have a common meaning for those who share the strain, so that they are willing to act, and there must be a dramatic event to precipitate action. Finally, there should be leaders who are able to sustain the movement until it becomes formally organized. At every point in this development, the instruments of social control, such as the government, the police, or public opinion, may play a decisive role in lessening or increasing the activity. They may also be important in determining its length and severity.

We may supplement this structural theory of social movement with an approach which stresses the role of specific politically relevant historical events as catalysts for student movements. This approach seems to confirm the views of those revolutionary theorists like Bakunin and Blanqui, who stressed the role of intellectuals and students as the inspirers, leaders, and often mass troops of the revolution. In the light of these theoretical frameworks it is easy to comprehend the origin and development of the student movement in the pre-Emergency period and its evanescence since then.

The Indian economy is characterized by a tension-ridden imbalance: the educational output is not commensurate with the absorptive capacity of the economy. Thus, between 1956 and 1974, the number of unemployed shot up 
from 5.3 million to over 15 million. The number of registered unemployed (only a fraction of the total) increased from 335,000 in 1951 to $9,315,000$ in 1975 - a twenty-eight-fold increase in twenty-four years. Nearly half of the registered unemployed had some educational qualification, including many with a university degree (quoted in Hiro, 1978, p. 85).

The ineffectiveness of the Constitution and the inability of the ruling party to solve any of these problems, combined with its incessant desire to remain in power, are glaringly exposed by the fact that between 1951 and 1971, the Constitution was amended twenty-two times, on an average once every eleven and one-half months. Between 1971 and 1974, there were fifteen amendments, roughly one every eighty days. Almost all these amendments had very little to do with the welfare of the people and were basically designed to strengthen the government's, particularly the ruling party's, position.

In 1974, the student movement was ably served by a leadership which was both experienced and commanded respect. Moreover, the movement started by the students developed into a broader political movement with the government as its target. Also important in this context were the dramatic events of 1974-1975 - such as police firings, imposition of President's Rule in Gujarat without dissolving the state assembly, the defeat of the Congress party in the Gujarat mid-term election, the Allahabad High Court judgement declaring the election of Indira Gandhi to the Lok Sabha null and void, etc. which provided the necessary élan to the movement.

Given the course of events, the student movement could have become full-blown. But, the government, realizing what was in store for it, ruthlessly crushed the movement during the Emergency. Student leaders were arrested, detained, and tortured. Student unions were converted into nominated associations for cultural activities. Resistance to this suppression was systematically destroyed.

When the Emergency was lifted after the defeat of the Congress party in the march 1977 Lok Sabha election, the student movement had lost its raison d'etre. But there were innumerable student agitations resembling those of the sixties. What are the prospects of the re-emergence of such a movement? The post-Emergency socio-economic scene being a continuation of the pre-Emergency one, one should only expect the reappearance of such a movement. But whether this expectation would materialize or not will depend on other conditions. In the first place, after joining hands in a movement and being responsible for the formation of a new government, the students seem to be obliged to refrain from any attempt at resurrecting the movement, at least in the near furture. Even if they attempt it, it will not be blessed by the political leaders who are in power.

Further, the various student and youth organizations which were once united seem to be clearly divided. For example, in Bihar, the Chhatra Sangharsha Samiti, which had led the 1974 movement, stands divided into four 
sometimes feuding camps. Added to this is the parallel opposition force of the left-wing student organizations like the AISF, the SFI and the Bihar Students' Association. However, the left- and right-wing opposition is not uniform throughout the country, or even in one state. In the recent JNU Students' Union election, the SFI and the AISF joined hands and this alliance was opposed by the Yuva Janata, whereas in the Delhi University Students' Union election, the SFI joined hands with the Yuva Janata to fight the Vidyarthi Parishad. But invariably the Congress-controlled National Students Union of India and the Youth Congress are the weak enemies of both the left- and the other right-wing student organizations.

As it stands today, student unrest has the necessary infrastructure for its transformation into a movement, and the potentiality of students in this regard has been indubitably proved. Whether such a transformation takes place in the near future depends much on the role of instrumental conditions, which at the moment seem to be unfavourable.

\section{References}

Abraham, A. (1978). "A report from Marathwada," Economic and Political Weekly 13: $1536-1540$.

Altbach, P. G. (1968a). "Student Politics and Higher Education in India," in P. G. Altbach, ed., Turmoil and Transition: Higher Education and Student Politics in India, pp. 17-73. Bombay: Lalvani Publishing House.

Altbach, P. G. (1968b). Student Politics in Bombay. Bombay: Asia Publishing House.

Amnesty International (1979). Summary of report on "Political imprisonment and torture in India," Economic and Political Weekly 14: 145, 147-150.

Banerjee, S. (1978). "JNU and the political power game," Economic and Political Weekly 13: $1542-1544$.

Dasgupta, S. (1974). The Great Gherao of 1969 (A Case Study of Campus Violence and Protest Methods). New Delhi: Orient Longman.

Ghosh, S. K. (1971). "Student revolution in India," Quest 70: 51-54.

Hiro, D. (1978). Inside India Today. London: Routledge and Kegan Paul.

Jafar, S. M. (1977). Student Unrest in India: A Select Bibliography. Gurgaon (Haryana): Indian Documentation Service.

Lipset, S. M. (1972). Rebellion in the University (A History of Student Activism in America). London: Routledge and Kegan Paul.

Mankekar, D. R. and Mankekar, K. (1977). Decline and Fall of Indira Gandhi. New Deihi: Vision Books.

Mehta, V. (1978). The Sanjay Story - from Anand Bhavan to Amethi. Bombay: Jaico Publishing House.

Oommen, T. K. (1974). "Student politics in India: the case of Delhi University," Asian Surve. 14: 777-794.

Pandit, C. S. (1977). End of an Era (The Rise and Fall of Indira Gandhi). New Delhi: Allied Publishers.

Ray, A. B. (1977). Students and Politics in India (The Role of Caste, Language and Region in an Indian University). New Delhi: Manohar Book Service. 
Ross, A. D. (1969). Student Unrest in India - A Comparative Approach. Montreal: McGill-Queen's University Press.

Selbourne, D. (1977). An Eye to India - The Unmasking of a Tyranny. Harmondsworth: Penguin.

Sharma, D. (1977). The Janata (People's) Struggle. New Delhi: Philosophy and Social Action.

Sharma, U., ed. (1978). Violence Erupts. New Delhi: Radha Krishna Prakashan.

Shils, E. (1968a), "Indian Students: Rather Sadhus than Philistines," in P. G. Altbach, ed., Turmoil and Transition: Higher Education and Student Politics in India, pp. 74-92. Bombay: Lalvani Publishing House.

Shils, E. (1968b). "Students, Politics, and Universities in India," Introduction to P. G. Altbach, ed., Turmoil and Transition: Higher Education and Student Politics in India, pp. 1-13. Bombay: Lalvani Publishing House.

Singhal, S. (1977). Academic Leadership and Student Unrest. New Delhi: Newman Group of Publishers.

Smelser, N. J. (1962). Theory of Collective Behaviour. London: Routledge and Kegan Paul.

Vishwa Yuvak Kendra (1973). The Dynamics of Student Agitations. Bombay: Somaiya Publications. 